\title{
Applying the Concept of Panarchy in Archaeogeography: the Example of the Resilience of Routes over the Longue Durée.
}

\author{
Appliquer le concept de panarchie en archéogéographie : l'exemple de la \\ résilience des itinéraires routiers dans la longue durée
}

\author{
Sandrine ROBERT ${ }^{1}$ \\ ${ }^{1}$ Ecole des Hautes Etudes en Sciences Sociales (EHESS), UMR Géographie-cités, sandrine.robert@ehess.fr
}

RÉSUMÉ. L'article traite de l'application du cadre conceptuel de la résilience écologique, à l'étude des itinéraires régionaux, décrits comme des systèmes résilients. Les itinéraires de grand parcours dans le Bassin Parisien ont été étudiés à travers les interactions entre les échelles macro, méso et micro. L'analyse montre qu'une grande partie du réseau français actuel remonte à l'Antiquité. Néanmoins, ce ne sont pas des routes spécifiques qui sont résilientes à travers le temps mais plutôt les itinéraires entre les pôles régionaux. Ils sont constitués de plusieurs chemins et routes qui coexistent, se substituent les uns aux autres ou sont abandonnés puis réutilisés. L'interaction entre les trois niveaux macro, méso et micro, possédant des rythmes différents de changement, favorisent la résilience du système routier dans le temps. L'itinéraire représente l'échelle macro ou niveau large et lent (certains itinéraires peuvent rester actifs depuis 2000 ans) tandis qu'à la micro-échelle, représentée par la structure matérielle des chemins et des routes, les changements sont beaucoup plus nombreux et fréquents. À l'échelle méso, le tracé des chemins et des routes présente des temporalités non linéaires et apparaît comme un niveau clé pour la résilience des itinéraires avec des possibilités de hiatus, de réutilisation, etc. Les concepts de cycle adaptatif et de panarchie, proposés par C. S. Holling et ses collaborateurs dans le domaine de la Resilience Theory peuvent alors être utilisés pour décrire la dynamique complexe des itinéraires régionaux.

ABSTRACT. This paper discusses the application of the resilience conceptual framework, proposed in ecological resilience, to the study of major route systems, described as resilient systems. Major routes in the north of France are studied at the macro-, meso-, and micro-scales. The analysis shows that a large part of the current French network originated in Antiquity. Nevertheless, no one specific road is resilient throught time. Rather, the itineraries are made of several paths and roads that may coexist, substitute one another, or are abandoned but then re-used. Three levels, corresponding to different rhythms of change, interact and account for the routes' resilience. The itinerary represents the macro-scale: broad and slow level (up until 2,000 years), while at the micro-scale, the structure of paths and roads undergoes numerous and frequent changes (less than 25 years). On the meso-scale, the path and road patterns present non-linear temporalities and appear as a key level for routes' resilience with possibilities of hiatuses, reuses, etc. The complex dynamic of routes can match the concepts of adaptive cycle and panarchy proposed by C. S. Holling and collaborators.

MOTS-CLÉS. résilience, routes, cycle adaptatif, panarchie, interscalarité, rythmes de changement

KEYWORDS. Resilience, Routes, Adaptive Cycle, Panarchy, Interscalarity, Rhythms of change

\section{Introduction}

In this paper, I propose to apply the resilience conceptual framework (as it has been proposed in the field of ecological resilience) to the study of major route systems. A major route is an organization that can be described as a resilient system because it is sufficiently stable to be observed over the longue durée. The relation resulting from the circulation of people, goods, information... between two centers produce paths and roads that we can study in archaeogeography. The routes database and the results of the study I have 
been conducting in the north of France will be described, and I will show how the dynamic of routes can match the concepts of adaptive cycle and panarchy proposed by Holling et al. (Gunderson \& Holling, 2002).

\section{The route database}

The study has been initiated in the context of my PhD (Robert, 2003) and then, developed within the framework of the Dynarif program (Dynamic and resilience of routes networks in Ile-de-France) that I managed with Nicolas Verdier (CNRS) between 2007 and 2014 (Robert \& Verdier, 2014). The study is now supported by the archaeological program ArcheoFab, Fabrique numérique pour l'archéologie (UMR 7041 Arscan) as part of the project Dynamique et Résilience des réseaux de circulation dans le Bassin Parisien (DYNAREP) ${ }^{1}$.

The aim of the study has been to accommodate the conceptual framework of ecological resilience conceptual framework to morphological method in archaeogeography as part of my full professorship research thesis, in 2020 (Robert, in press).

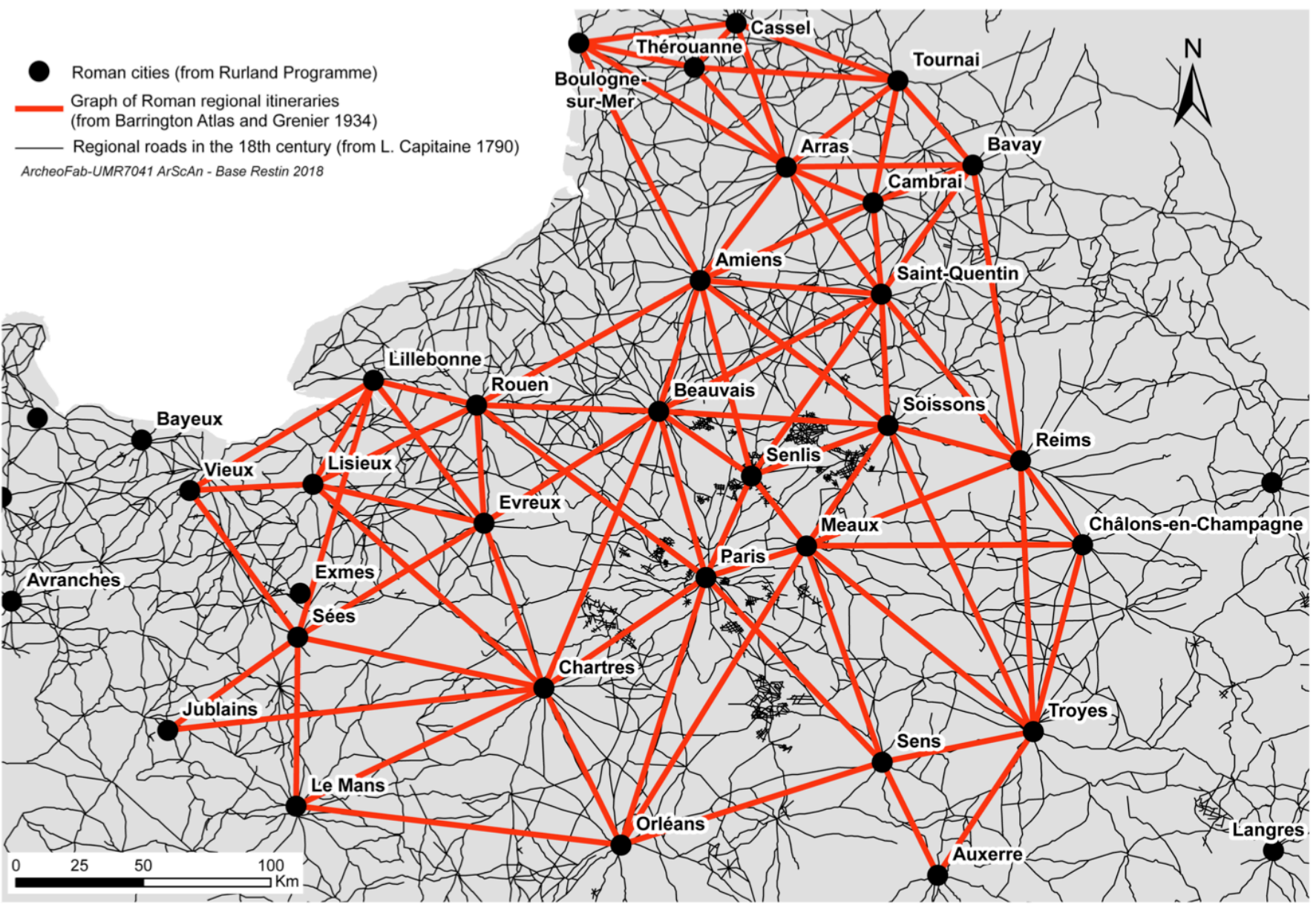

Figure 1. Regional routes studied in the Parisian Basin @ Sandrine Robert, $2019^{2}$

On the macro-scale, I have studied 111 regional routes in the Parisian Basin (northwest of France), registered by the French Ordnance Survey cartography (cartes d'État Major $-19^{\text {th }}$ century). I have used general cartography to recreate five states of routes spanning from the Antiquity until the present day using a

\footnotetext{
${ }^{1}$ https://abp.hypotheses.org/

${ }^{2}$ The map of the Roman cities comes from the Rurland Programme (The Rural lands of North-eastern Gaule, from the late La Tène to the late antiquity, M. Réddé coord. https://abp.hypotheses.org). The maps of Etat-Major 320000 (19 century), L. Capitaine (1790) and the maps compiled in the book of Albert Grenier (Grenier, 1934) have been georeferenced and vectorized by Laurent Costa in the ArcheoFab programme (https://abp.hypotheses.org/).
} 
GIS (figure 1). To create the graph of regional roman itineraries, I have used the database elaborated from the Barrington Atlas (Talberg, 2000) ) $^{3}$ and the maps compiled in the handbook of Albert Grenier (Grenier, 1934). For the Middle Ages, some of the merchant routes converging to Paris have been mapped relying on La Guide de Charles Etienne (1553) by French historians (Bonin \& Mandrou, 1961). For the early modern era, the maps of Louis Capitaine (1790 and 1800) provide a generalization of Cassini's Map while IGN database detail today's network (table 1).

Table 1. Sources using to observe five states of regional route system in the Parisian Basin @ Sandrine Robert, 2019

\begin{tabular}{|c|c|c|c|c|c|}
\hline & Antiquity & Middle Ages & Early Modern era & $19^{\text {th }}$ Century & $20^{\text {st- }} 21^{\text {st }}$ Centuries \\
\hline Macro-scale & $\begin{array}{l}\text { Barrington Atlas } \\
\text { data }\end{array}$ & $\begin{array}{c}\text { Charles Etienne } \\
1553 \\
\text { (Bonin \& Mandrou, } \\
1961)\end{array}$ & $\begin{array}{l}\text { L. Capitaine } 1790 \\
\text { and } 1800 \\
\text { (ArcheoFab data) }\end{array}$ & $\begin{array}{c}\text { Etat-Major } 320000 \\
\text { (ArcheoFab data) }\end{array}$ & $\begin{array}{l}\text { IGN - Route } 120 \\
\text { IGN - Route } 500 \\
\text { (IGN data) }\end{array}$ \\
\hline Meso-scale & $\begin{array}{l}\text { Pattern study } \\
\text { (Robert, 2003) }\end{array}$ & $\begin{array}{c}\text { Texts, pattern study } \\
\text { (Robert, 2003) }\end{array}$ & $\begin{array}{c}\text { Texts, pattern study } \\
\text { (Robert, 2003) }\end{array}$ & $\begin{array}{c}\text { Texts, pattern study } \\
\text { (Robert, 2003) }\end{array}$ & $\begin{array}{l}\text { Pattern study, } \\
\text { observation }\end{array}$ \\
\hline Micro-scale & $\begin{array}{c}\text { Archaeology } \\
\text { (Robert \& Verdier, } \\
\text { 2014) }\end{array}$ & $\begin{array}{c}\text { Archaeology } \\
\text { (Robert \& Verdier, } \\
\text { 2014) }\end{array}$ & $\begin{array}{c}\text { Archaeology } \\
\text { (Robert \& Verdier, } \\
\text { 2014) } \\
\text { Cartography }\end{array}$ & $\begin{array}{c}\text { Cartography } \\
\text { (Robert \& Verdier, } \\
\text { 2014) }\end{array}$ & $\begin{array}{l}\text { Cartography } \\
\text { Geography }\end{array}$ \\
\hline
\end{tabular}

At the meso-scale, I have worked on a particularly rich and detailed database concerning Val-d'Oise (a french departement northwest of Paris) where all the paths traced in the cadastral plan at the beginning of the nineteenth century were georeferenced and collected in a GIS ${ }^{4}$. I was able to study nine ancient itineraries in detail (Robert, 2003) (figure 2).

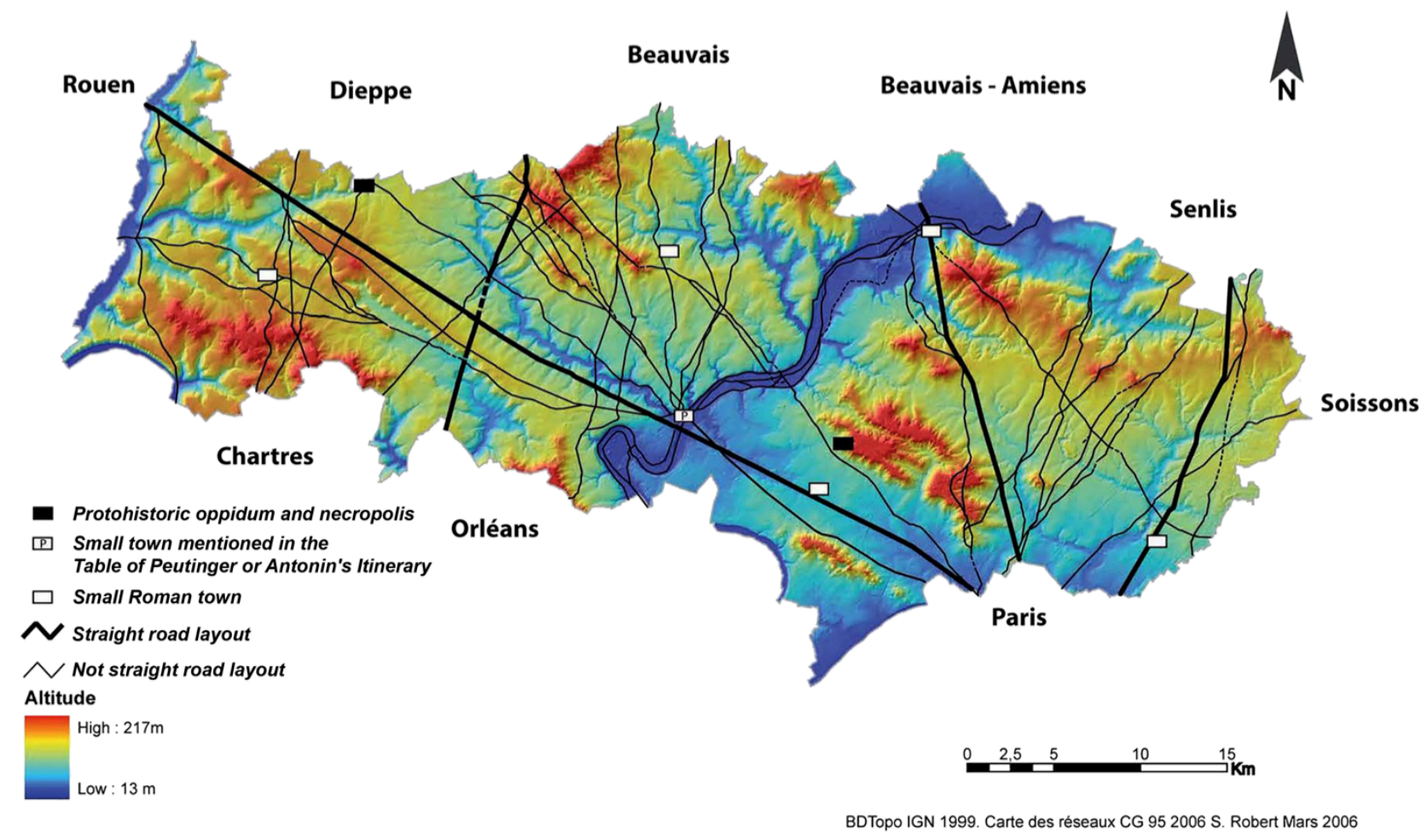

Figure 2. Roads and paths of the ancient regional routes in Val-d'Oise

(C) Sandrine Robert, from Robert (2003)

\footnotetext{
${ }^{3}$ The information of the Barrington Atlas comes from the website: https://darmc.harvard.edu/home.

${ }^{4}$ Database elaborated by the Service Archéologique du Conseil Départemental du Val-d'Oise (Costa \& Robert, 2008).
} 
On the micro-scale, I worked with archeological information collated in the framework of the Dynarif program, which enabled me to draw comparisons between the reconstruction of ancient patterns and 115 states of paths and roads observed by archeologists (Robert \& Verdier, 2014).

\section{Results}

Out of the 111 modern itineraries studied, I observed that 83 are registered in the Barrington database. Thus, a large part of today's French network can be traced back to Antiquity. And out of these 83 itineraries, only two are local roads today: 37 are toll superhighways and the others are major or regional highways (figure 3).

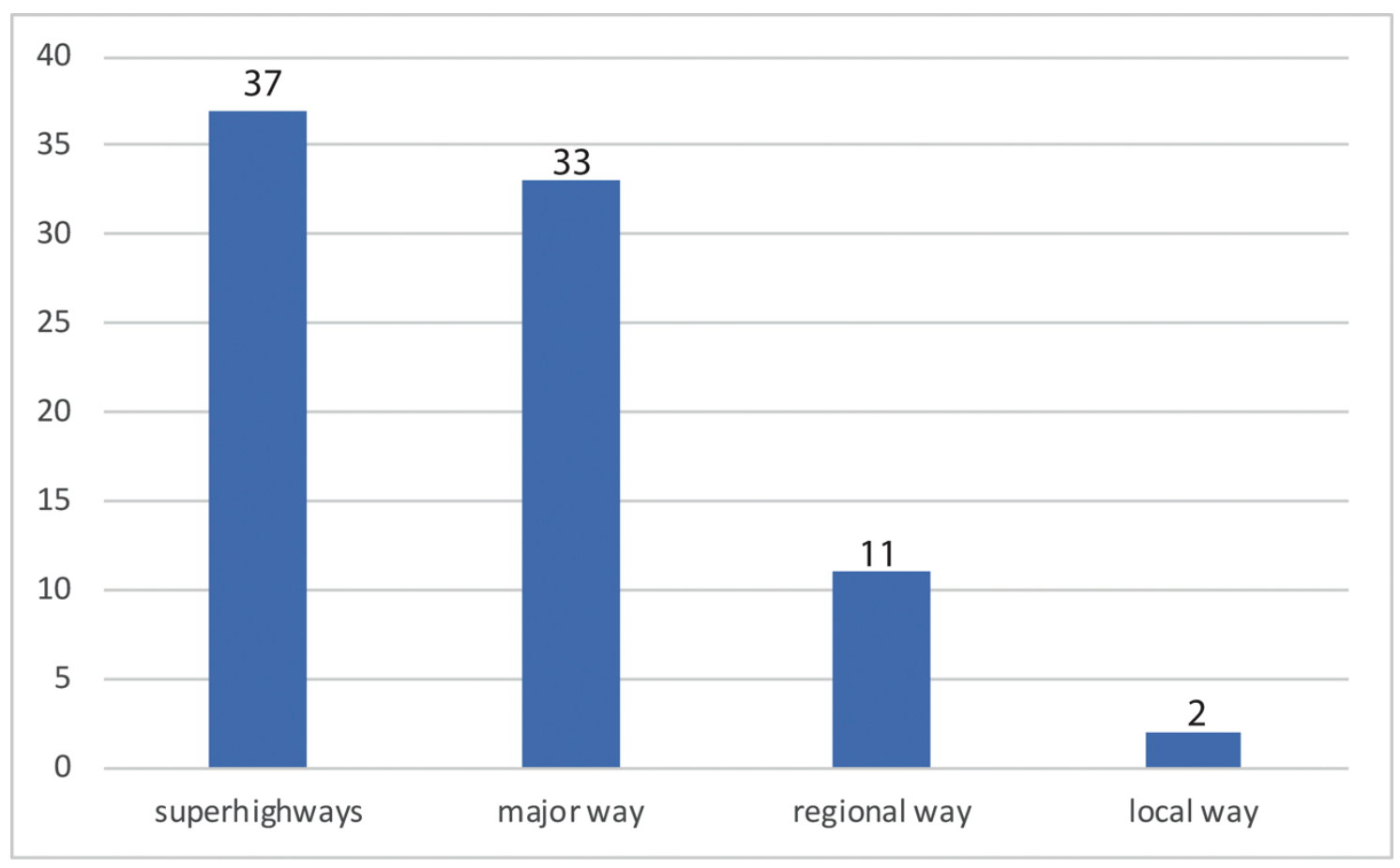

Figure 3. Current hierarchies for 83 itineraries depicted in the Barrington Atlas @ Sandrine Robert, 2019

Nevertheless, the meso-scale analysis shows that there is not one specific road that is resilient across time. The itineraries are composed of several paths and roads that coexist, or substitute for one another, or are abandoned but then re-used. For this reason, I prefer to refer to routes or itineraries rather than to roads (figure 2).

For example, the Paris-Rouen itinerary has been extremely resilient since Antiquity but the current French motorway does not match the Roman Chaussée Jules-César that was the first strategic road built to connect the two urban centers. In Val-d'Oise, I have identified an average of three different road patterns for one resilient itinerary (Robert, 2003). And it is precisely the transformation of these routes that renders them resilient. The transformations of the initial road, which at first glance may seem reasonably interpreted as disruptions, alterations, are in fact the conditions of the resilience of the entire route. Therefore, in my view, Holling's definition of resilience, coined in 1978, fits perfectly the description of routes system: "resilience is a property that allows a system to absorb and utilize (or even benefit from) change." (Holling, 1978 : 11).

As a result, I have identified three levels that interact and this interaction produces routes resilience. These levels correspond to different rhythms in change (table 2). On the macro-scale, the connections between centers have endured across time: over more than two thousand years for many itineraries. I argue that the itinerary represents the broad and slow-evolving level. On the micro-scale, the structure of paths and roads undergoes numerous and frequent changes. For example, we have identified that the Chaussée JulesCésar was the object of four successive foundations between the 1st and the 3rd century. In some spots, the road was completely rebuilt every 25 years (Robert \& Poirier, $2014: 162$ ). I consider that the level of the 
road structure is the small and fast-evolving level. It must indeed adapt quickly to the phenomena of wearing out, the evolutions in the means of locomotion, the aspirations to increase speed in traveling, etc. On the meso-scale, the path and road patterns undergo numerous changes too. And it thus appears as a key level for itineraries' resilience. Indeed, I have studied instances when regional traffic is hampered by the local urban fabric. In various cases, the creation or the re-use of an ancient path or road pattern emerges as a solution to ensure that the regional traffic may proceed.

Table 2. Different rhythms in resilience of roman itinerary @ Sandrine Robert, 2019

\begin{tabular}{|c|c|c|c|}
\hline Level & Large and slow & Intermediate size and speed & Small and fast \\
\hline Route System & connection, itinerary & path and road pattern & structure \\
\hline Rhythm (years) & $\begin{array}{c}2,000 \\
\text { (calculated on the basis of 111 } \\
\text { routes in the Parisian Basin) }\end{array}$ & $\begin{array}{c}10,200,300,500,2,000, \text { reuse } \\
\text { (calculated on the basis of 9 routes } \\
\text { in Val-d'Oise) }\end{array}$ & $\begin{array}{c}\text { (calculated on Chaussée Jules- } \\
\text { César laps between two re- } \\
\text { foundations) }\end{array}$ \\
\hline
\end{tabular}

I have thoroughly studied the stretch of the Dieppe-Paris road across Val-d'Oise. The itineraries can be traced back to the Middle Ages and in Pontoise, the road passed through the narrow and steep medieval streets. In the nineteenth century, a road was built in the medieval walls' moat allowing for the carters to drive across the city faster (Robert, 2011). At the beginning of the twenty-first century, the traffic of this road was very congested when crossing the village of Marines because of traffic lights and car parking causing obstruction. In 2002, the department authorities built a diversion reusing an old path that had been excavated in Les Carreaux and which dated back to the $7^{\text {th }}$ century. I view that path and its road patterns appear as the intermediary level that facilitates connections between the regional and local scales. Its rhythm is variegated (from ten to 2,000 years in case of reusing Roman roads), and this level presents non-linear temporalities with possibilities of hiatuses, reuses etc. (table 2). Thus, I will argue that this description of regional routes' resilience matches the adaptive cycle and panarchy model developed by Holling and collaborators.

\section{Using adaptive cycle and Panarchy}

C. S. Holling summarized the dynamics of socio-ecological systems in the form of an adaptive cycle in which four phases are distinguished: a development or exploitation phase $(\mathrm{r})$, a conservation phase $(\mathrm{K})$ or slow accumulation of resources, a release phase (or $\Omega$ ) which is a phase of "creative destruction" as it leads at the same time to the reorganization (phase $\alpha$ ) of the system (Holling, 1986). In 2002, the adaptive cycle model is articulated in a so-called panarchic model (Gunderson \& Holling, 2002) that Walker et al. describe as: "the influence of the states of the system (including where they are in their adaptive cycles) at scales above and below the focal scale, which affects the other three aspects by impacting the system directly (from the finer scale) or changing the stability landscape (from the coarser scale)" (Walker et al., 2004: fig. 2). The panarchic model thus articulates three scales of adaptive cycles: large and slow-evolving / intermediate and fast-evolving / small and very fast-evolving. The originality of the panarchic model is that it introduces connections between these different levels. The revolt arrow indicates that events occurring in the fast and very fast cycles can influence the slower levels and cause them to enter their $\Omega$ phase of creative destruction. In contrast, remember arrows can intervene at the time of the renewal (alpha) phase and facilitate reorganization by allowing the system to draw on potential accumulated at other levels. The dynamics of the different cycles can be accelerated or slowed down in case of interactions between the different cycles (Gunderson \& Holling, 2002).

The organization of routes, before the $18^{\text {th }}$ century, with the presence of a set of patterns for one itinerary, could be associated with the first phase of the adaptive cycle called $r$ phase or exploitation phase. In the Dieppe-Paris connection case, the archeogeographical study has shown at least six paths in the Middle Ages. 
At the time, the connection had the shape of various converging lines rather than one specific road. This exploitation phase is characterized by a diversity of possibilities and a wide spatial occupation (figure 4).

In the $18^{\text {th }}$ century, when the royal roads network was built, engineers concentrated the traffic in only one pattern that was re-organized with a straight layout, ditches, cobblestone, etc. I argue that this phase can correspond to the K-phase or conservation phase of the adaptive cycle. The building of the roads improved the traffic but it converged on one pattern only, which means a loss of diversity and a potential loss of resilience. Indeed, at the local scale, the activities are more and more connected with the main road, and in turn, slow traffic down. This was the case for the village of Marines when shops, hospital, industrial activities, etc. developed and concentrated along the Paris-Dieppe road resulting in a slowdown of the traffic.

At the beginning of the $21^{\text {st }}$ century, the situation was very burdensome with 12,000 vehicles per day, including many trucks, circulating on the road. During the release phase ("creative destruction" or $\Omega$ phase), a diversion was built, for the traffic to bypass the center of the village (figure 4). The diversion was in part built on the pattern of the $7^{\text {th }}$ century path excavated in Les Carreaux in 2001, it was still a path and represented one of the boundaries to the municipality. In Les Carreaux, archaeologist excavated a village of the $7^{\text {th }}$ and $8^{\text {th }}$ centuries (Devals, 2003).

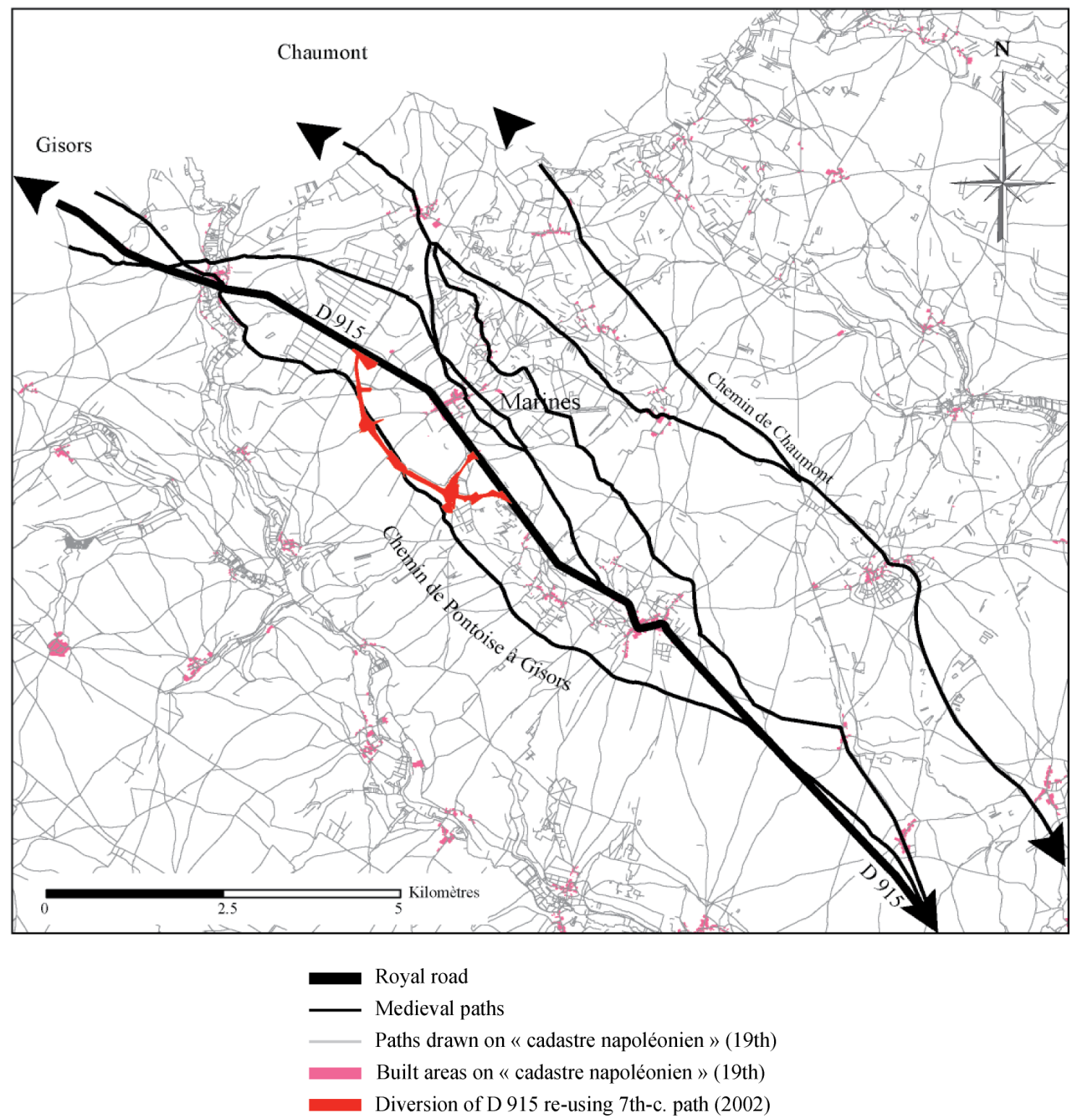

Figure 4. Collection of road layouts marking the different phases of adaptation of the Paris-Dieppe itinerary by Gisors à Marines (Val-d'Oise) @ from Robert (2003) 
Thus, the large and slow-evolving level has been resilient for at least thirteen centuries because it was preserved by the possibility to use a former pattern at the intermediate level. I argue that it represents an example of the "remember" connection of in the panarchy model (Gunderson \& Holling, 2002: 75-76) (figure 5).

Conversely, the small level (the structure of the road) had to be changed quickly and sent an arrow of "revolt" toward the global level because the structure was no longer adapted to the regional traffic. When a crisis occurs at the small level (in this case, the road running through villages), the solution depends on the potential of renewal passed on by the intermediate level (the stock of path and road patterns inherited from the past) (figure 5). We can adapt the panarchy model to the Pontoise case as well: when, in the 19th century, the city converted the medieval wall's moat into a road, which carters used for regional traffic (Robert, 2011).

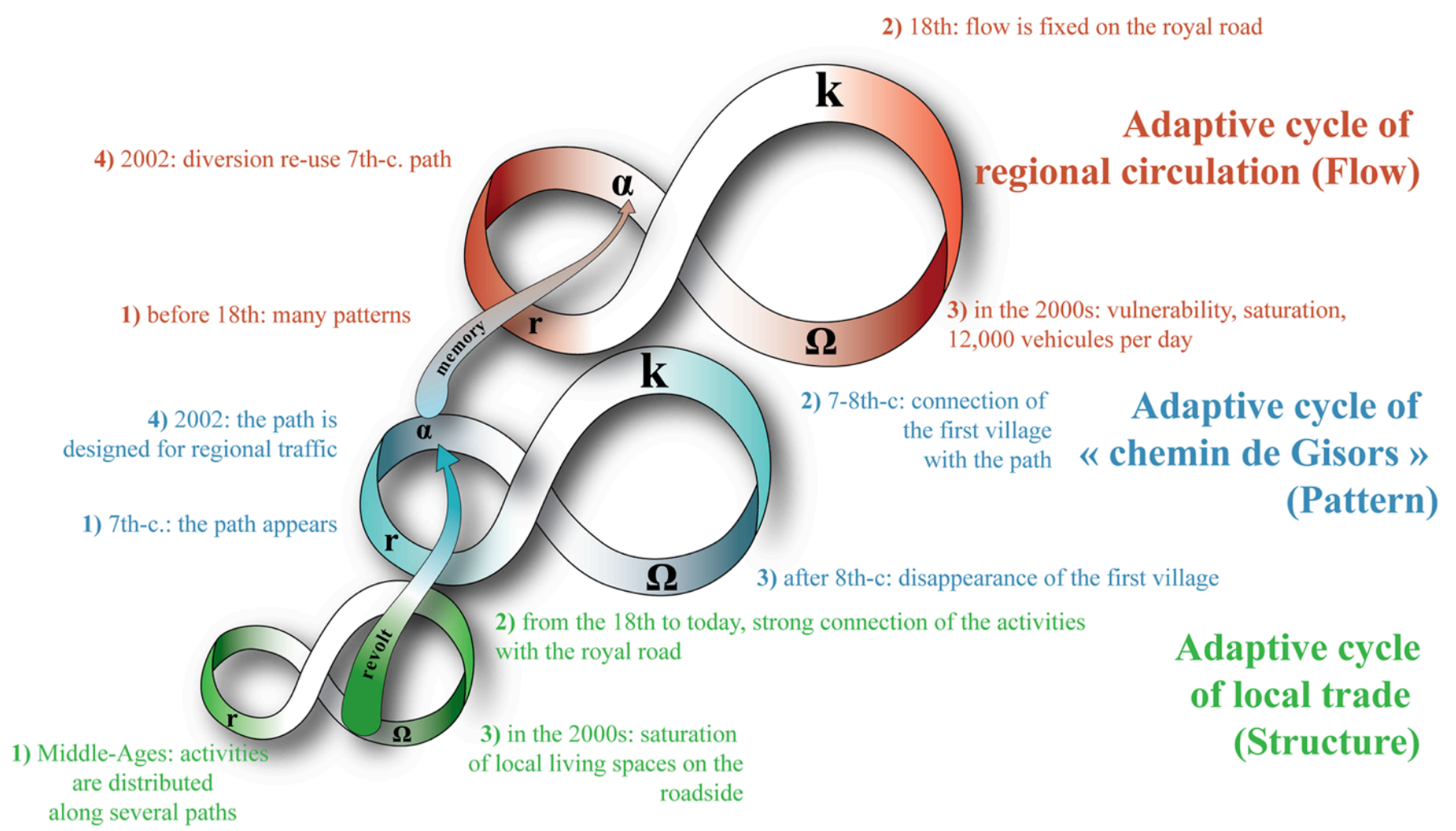

Figure 5. Adaptation of panarchy to the case of the route Paris-Dieppe in Marines, France @ Sandrine Robert, Laurent Costa del., 2019

\section{Conclusion}

To conclude, the study of spatial systems in the longue durée (spatial settlements, routes systems, land plot systems, etc.) allows us to observe adaptive cycles and to highlight the vital interaction between different levels to ensure the resilience of the whole system.

According to this approach, forms and traces inherited from the past appear as potential active agents of present or future systems. As such, they belong to the trajectory of the systems.

Thus we can complete diachrony and synchrony, traditionally used in social sciences with others temporalities like hysteresis used in the study of alternative attractors (Scheffer et al., 2001) or others temporalities proposed by G. Chouquer as uchronie or tapochronie in archaeogeography (Chouquer, 2000). With uchronie, from the moment a form is created, it imprints a mark, a trace that it becomes a potentiel that could be reused in the future. It may be related to hysteresis whereas taphochronie may describe the permanent disappearance of a structure that could occur after a regime shift (Robert, in press). 
REMARQUE. Ce texte est publié suite à sa présentation dans la session organisée par la commission Theory and methods in Landscape archaeology - Archeogeography lors du XVIII ${ }^{\mathrm{e}}$ Congrès de l'Union Internationale des Sciences Préhistoriques et Protohistoriques (UISPP), le mardi 5 juin 2018 à l'Université Paris 1 PanthéonSorbonne. L'UISPP, fondée en 1931, est membre du Conseil International de philosophie et de sciences humaines, et associée à l'UNESCO et à l'Union Académique Internationale (https://www.uispp.org/).

REMARK. This text is published following its presentation at the session organized by the commission Theory and methods in Landscape archaeology - Archeogeography at the XVIII ${ }^{\text {th }}$ Congress of the International Union of Prehistoric and Protohistoric Sciences (UISPP), Tuesday, June 5, 2018 at the University Paris 1 PanthéonSorbonne. The UISPP, founded in 1931, is a member of the International Council for Philosophy and Humanistic Studies, and is associated with UNESCO and the International Academic Union (https://www.uispp.org/).

\section{Conflicts of interest}

No conflict of interest to declare.

\section{Evaluation}

Reviewer for this paper is Michelle Elliott.

\section{Peer-reviewer responsibilities}

Reviewer evaluations are given serious consideration by the editors and authors in the preparation of manuscripts for publication. Nonetheless, being named as a reviewer does not necessarily denote approval of a manuscript; the editors of Archaeology, Society and Environment take full responsibility for final acceptance and publication of an article.

\section{Bibliographical references}

Bonin, S., Mandrou, R., 1961. La France de Charles Estienne. Annales. Économies, Sociétés, Civilisations. 16(6), $1121-1130$.

Chouquer, G., 2000. L'étude des paysages : essais sur leurs formes et leur histoire. Errance, Paris, 208 p.

Costa, L., Robert, S., 2008. Développement d'un outil de géo collaboration au sein d'une collectivité territoriale : l'exemple de l'Atlas historique du Val-d'Oise. Archeologia e calcolatori. 19, 123-36.

Devals, C., 2003. Marines-Santeuil - Les Carreaux. Document final de synthèse de fouille préventive de mars à août 2001. DRAC-SRA-Ile-de-France, INRAP, CG-Val-d'Oise, Saint-Denis, 274 p.

Grenier, A., 1934. Manuel d'archéologie gallo-romaine. Deuxième partie. L'archéologie du sol. Les routes. Picard, Pas, $468 \mathrm{p}$.

Gunderson, L.H., Holling, C.S. (Éds.), 2002. Panarchy: understanding transformations in human and natural systems. Island Press, Washington, $507 \mathrm{p}$.

Holling, C.S. (Éd.), 1978. Adaptative Environmental Assessment and Management. John Wiley and Sons, Chichester, New York, Brisbane, Toronto, $376 \mathrm{p}$.

Holling, C.S., 1986. The resilience of terrestrial ecosystems; local surprise and global change, in: Clark, W. C., Munn, R. E. (Éds.), Sustainable Development of the Biosphere. Cambridge University Press, Cambridge, 292-317.

Robert, S., 2003. L'analyse morphologique entre archéologie, urbanisme et aménagement du territoire. Exemples d'études de formes urbaines et rurales dans le Val-d'Oise. Thèse de Doctorat, Université Paris 1 - PanthéonSorbonne, Paris, 1391 p.

Robert, S., 2011. La ville de Pontoise au Moyen Âge : entre impensé et stratégie des élites. Archéologie médiévale. 41, 123-167.

Robert, S., in press. La résilience : persistance et changement dans les formes du paysage. ISTE, London, $286 \mathrm{p}$. 
Robert, S., Poirier, B., 2014. La chaussée Jules-César, résilience d'une grande voie antique dans le Vexin français, in : Robert, S., Verdier, N. (Éds.), Dynamique et résilience des réseaux routiers. Archéogeographes et archéologues en en région Ile-de-France. FERACF, Tours, 151-169.

Robert, S., Verdier, N. (Éds.), 2014. Dynamique et résilience des réseaux routiers. Archéogeographes et archéologues en en région Ile-de-France. FERACF, Tours, $259 \mathrm{p}$.

Scheffer, M., Carpenter, S., Foley, J.A., Folke, C., Walker, B., 2001. Catastrophic shifts in ecosystems. Nature. 413(6856), 591-596.

Talbert, R.J.A., 2000. Barrington Atlas of the Greek and Roman World. Princeton University Press, Princeton, 280 p.

Walker, B., Holling, C.S., Carpenter, S., Kinzig, A., 2004. Resilience, Adaptability and Transformability in Socialecological Systems. Ecology and Society. 9(2), 5. 